\title{
A Reclaimed Wastewater Allocation Optimization Model for Agricultural Irrigation
}

\author{
Ahmed A. Aljanabi ${ }^{1}$, Larry W. Mays ${ }^{1} \&$ Peter Fox $^{1}$ \\ ${ }^{1}$ School of Sustainable Engineering and the Built Environment, Arizona State University, Tempe, AZ, USA \\ Correspondence: Larry W. Mays, School of Sustainable Engineering and the Built Environment, Arizona State \\ University, Tempe, AZ. Email: mays@asu.edu
}

Received: March 26, 2018

Accepted: April 9, 2018

Online Published: April 25, 2018

doi:10.5539/enrr.v8n2p55

URL: https://doi.org/10.5539/enrr.v8n2p55

\begin{abstract}
Climate change, pollution, civil conflicts, political instability, and a high rate of population growth all contribute to water shortages in Iraq which are predicted to increase in the future. Due to the importance of agriculture in Iraq which forms more than 75 percent of total demand, a sustainable agricultural water allocation scheme is necessary to find practical and applicable water conservation measures that helps mitigate the impact of potential droughts and water shortages. An agricultural irrigation reclaimed wastewater allocation optimization model was developed to optimally allocate crops and reclaimed wastewater (RW) on cultivated farmlands in order to maximize the net benefit. The optimization model is formulated using mixed-integer nonlinear programming (MINLP) solved by the branch and reduce optimization navigator (BARON) in the general algebraic mathematical solver (GAMS). The model maximizes the net farm income to determine the cultivated crop assigned to each farmland using three types of reclaimed wastewater (RW); tertiary treated wastewater; secondary treated wastewater; and primary treated wastewater. Constraints in the optimization model include: (1) reclaimed wastewater availability constraints and (2) irrigated farmlands constraints. The optimization model has been applied to 7045 hectares of farms located in the Alrustumia district to the south east of Baghdad, Iraq with $5.5 \times 10^{5} \mathrm{~m}^{3} / \mathrm{d}$ of treated wastewater. The use of tertiary treated wastewater provided the greatest net benefit under most scenarios evaluated while primary effluent provided the lowest net benefit as only low value crops could be cultivated.
\end{abstract}

Keywords: Optimization, agriculture, water allocation, reclaimed wastewater, irrigation

\section{Introduction}

Water scarcity in Iraq is between truth and fiction. For thousands of years, Iraq has been known as Mesopotamia with abundant water from the Tigris and the Euphrates Rivers available for the Fertile Crescent. The Tigris and the Euphrates Rivers have experienced a significant reduction in their annual transboundary water flow since 1999. In 1998, the International Water Management Institute (IWMI) addressed Iraq as one of the critical water scarce countries (Seckler, 1998). Most of Iraq's water is transboundary water. The Euphrates River gets 88 percent of its water from Turkey and 9 percent from Syria. While 56 percent of the Tigris River water is from Turkey and 12 percent is from Iran. Those two rivers also experience significant water demands before they cross the Iraqi border.

More severe shortages in surface water resources are projected as flow in Iraq's rivers decreases and demands increase in Turkey, Syria, Iran, and Iraq along with the uncertainty associated with climate change. A water shortage in Iraq is an expected consequence due to the $50 \%$ or greater decline in transboundary water supplies from Turkey and Iran (FAO, 2016), as shown in Figure 1.

Water shortage forms a significant concern in Iraq that should be evaluated precisely. The previously mentioned factors have left negative impacts on the infrastructures, economy, and renewable water resources. Iraq experiences both water quality and quantity problems that are not being addressed by water resources management and thereby adversely affect the agricultural sector especially in the southern provinces downstream Baghdad. For instance, due to the water shortage in 2007-2009, there was a severe decline in agricultural productivity along the Tigris and Euphrates river basins (Shean, 2008). Crop production was reduced to one half of its usual rate of production and many farmers abandoned their agricultural lands. Consequently, agricultural crops, meats and many other related products are currently imported into Iraq resulting in elevated costs to consumers (UNDP, 2009). It has been projected that water scarcity may influence the relationship among Iraq's southern provinces due to their total reliance on agriculture. 


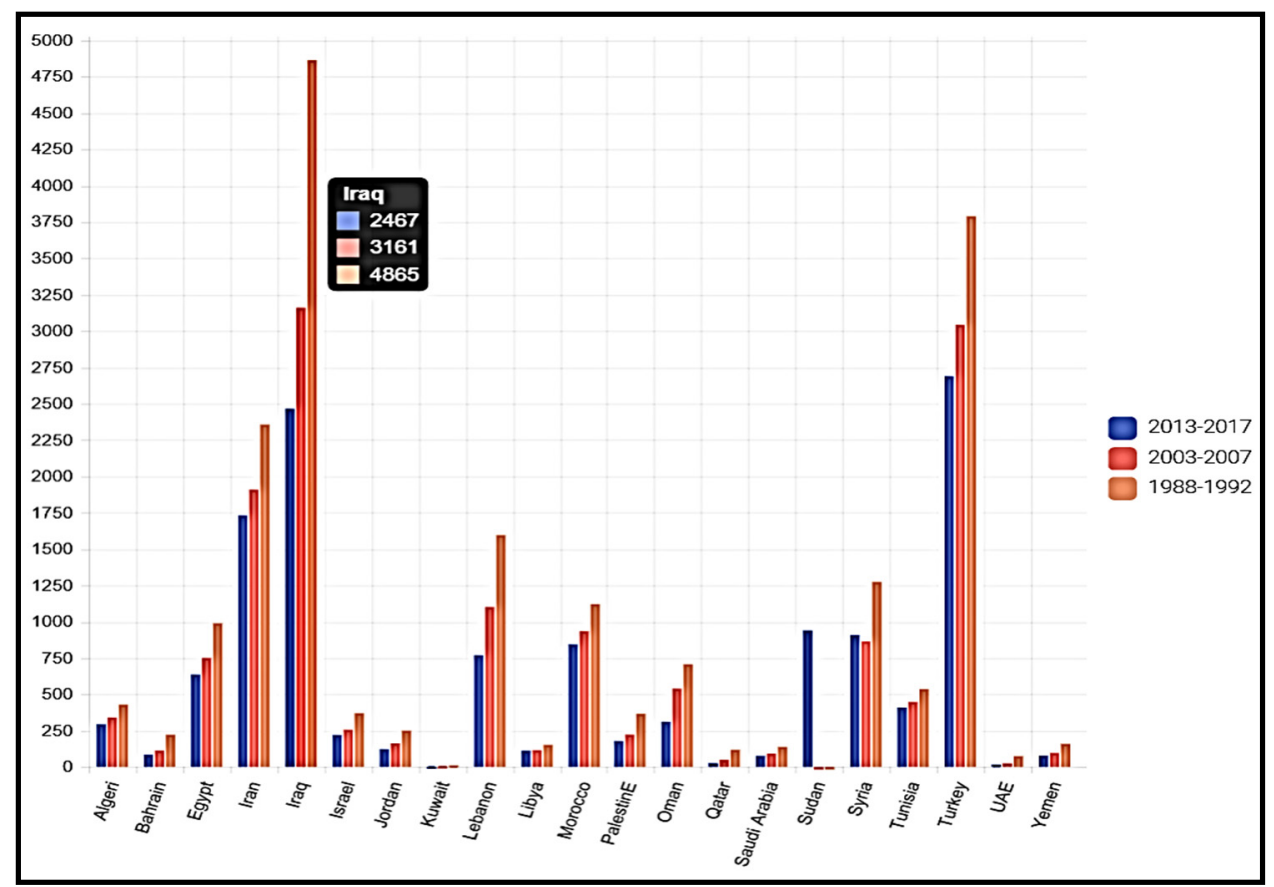

Figure 1. Annual renewable water resources in MENA countries ( $\mathrm{m}^{3} /$ capita/yr) (FAO, 2016)

Agricultural irrigation is the major consumptive use of water in many regions around the world and there is significant interest to optimize water use to maximize its economic outcomes and avoid water scarcity (MoradiJalal et al., 2007). In Iraq, agricultural water demand forms more than 75 percent of total demand (MoWR, 2015).

Rapid and comprehensive solutions must be considered to provide sustainable and reliable water resources which also meet quality standards. An integrated agricultural irrigation water management system requires a robust infrastructure to assure sustainability to avoid recent and future expected water shortages in Iraq. This may be achieved fairly allocating water for agricultural among farmlands. Many integrated water allocation systems have been practiced in many regions around the world which have an obvious role in balancing agricultural demand with other demands with positive economic and societal impacts. Thus, it is of great significance to take land use as a critical factor along with water allocation in river basins.

The practice of wastewater reuse in many regions around the world has bloomed due to the lack of fresh water sources. Reusing wastewater has gained an increased acceptance among people around the world as a reliable alternative and sustainable source of water for many applications. A high demand for agriculture along with proximity to wastewater treatment plants make reuse of wastewater for agriculture logical in many cases. Other uses for treated wastewater include environmental restoration, toilet flushing, cars washes, cooling towers and various industrial uses are practiced today in almost all arid and semi-arid regions all over the world. Consequently, wastewater treatment technologies have been developed accordingly to satisfy the quality standards required for different uses. Therefore, the traditional impression and concerns about wastewater reuse due to its low quality has changed. Wastewater reuse has been practiced in many applications and has even been integrated into drinking water supplies through groundwater recharge and indirect potable reuse.

In the Middle East, there has been a significant increase in reuse of wastewater as an alternative and reliable water resource. However, Iraq has not implemented planned wastewater reuse even though Baghdad produces more than $1.0 \times 10^{6} \mathrm{~m}^{3}$ of treated wastewater that is discharged to the Tigris River after secondary treatment. Iraq's renewable water supply comes primarily from the Tigris and the Euphrates Rivers, groundwater sources, rainwater harvesting, and limited desalination plants. Over the recent history, Iraq has been suffering a lot from political instability which has reflected negatively on its economic stability.

About 8 million hectares is the agricultural area in Iraq, which forms $70 \%$ of the total cultivated area. About $40 \%$ - $50 \%$ of this area is irrigable and is located along river basins while the remainder is rain feed and is in the northeastern plains and mountain valleys (Al-Ansari, 2013). The irrigated area is mainly supplied by water from the main rivers, and only $7 \%$ of the area is supplied by ground water (World Bank, 2006). Due to fallow practices 
and the unstable political situation, only 3 to 5 million hectares are now cultivated annually. In 1993, the estimated cultivated land were only 3.73 million hectares of which 3.46 and 0.27 million hectares consisted of annual and permanent crops respectively (Al-Ansari et al., 2012). In 2014, the World Bank estimated the cultivated farmland area in Iraq is about $9.27 \times 10^{6}$ hectares (World Bank, 2017).

Although Iraq's agricultural water demand is predicted to decrease by 55 percent by 2030 if irrigation is modernized, agriculture will still be the largest user of water going into the future (Evans et al., 2008). At the same time, the demands for municipal, industrial and tourism are predicted to increase, leading to an increase of the total water demand in the future. Wastewater reuse should be a primary player to mitigate water shortages for irrigation purposes. This is particularly true since agricultural lands south of Baghdad that have been deserted could be reliably irrigated with wastewater.

\section{Literature Review}

Developing an integrated reclaimed wastewater allocation optimization model for agricultural irrigation purpose is crucial in water scarce regions to mitigate water shortages, to control water wastage, and to maximize agricultural net benefit. This topic has led many researchers to focus on the development of agricultural irrigation models that consider economics, regional water resource allocation, and/or to test new water appropriation rules and policies (Benetti, 2008). A Computer Aided and Management Simulation of Irrigation Systems model (CAMSIS) to simulate farm income was developed (Burton, 1994). The model applied different water allocation rules and polices under water shortage or drought scenarios in East Africa. Paul et al (2000) developed a multi-level approach to solve problems related to seasonal and intra-seasonal agricultural irrigation water allocation in a semiarid region of Punjab, India. The approach considers the competition of the crops for irrigation water and farmed area. Dynamic programming approaches were developed to optimize irrigation scheduling (Rao et al., 1988, Naadimuthu, et al., 1999). An agricultural water allocation system (SAWAS) model was developed by Salman et al (2001) to be used as a decision-making tool for planners of agricultural production on both local and regional levels adopting an agricultural water allocation system model using linear programming. The model is based on the analysis of interseasonal irrigation water allocation and their effects on the net farm income. An agricultural irrigation water allocation optimization model was presented by Shangguan et al. (2002) using multiple water resources allocation. The model shows that the obstacles in using dynamic programming with multiple dimensions could be overcome. Brown, et al (2002) developed an AQUARIUS model to evaluate temporal and spatial allocation of flows among competing water uses in a river. A stochastic dynamic programming optimization model was developed by Ghahraman and Sepaskhah (2004) which optimizes the agricultural water allocation to a predetermined multiple cropping pattern in Iran. Álvarez et al (2004) described the MOPECO model for irrigation water management in a semi-arid area of Spain and drew a conclusion that the irrigation depth for maximum benefits is lower than that necessary to obtain maximum production.

Georgiou and Papamichail (2008) developed a non-linear programming optimization model to maximize the total farm income using an integrated soil water balance. The model was applied on the Havrias River in Northern Greece to determine the optimal reservoir releases, the water allocation for irrigation purposes, and the optimal cropping pattern for irrigated farmlands. An irrigation scheduling problem was evaluated using a Genetic Algorithm (GA) (Haq et al., 2008). Solving the same problem, the powerful role of using a GA was demonstrated in comparison to the use of an integer programing. A methodology was proposed by Sadegh et al. (2010) based on Shapely games to be used in water resources allocation among different users for the Karoon River basin in Iran with the goal of developing an equity standard to increase the total net benefit of the system. Simultaneous irrigation scheduling was evaluated using a GA comparing the stream tube model with the time block model (Haq \& Anwar, 2010). A stochastic nonlinear programming model with multiple objectives was used by You et al. (2011) to aid in multi-objective decision-making considering the Heihe River as a case study. An Inexact Roughinterval Fuzzy Linear Programming IRFLP model was constructed by Lu et al. (2011) to make a comparison between the IRFLP model and an interval-valued linear programming model for water allocation to provide more information for decision makers. The IRFLP was capable of handling the interaction between dual intervals of highly uncertain parameters, as well as their joint impact on the system.

Fotakis and Sidiropoulos (2012) developed a multi-objective evolutionary algorithm to simultaneously solve the problem of land use planning and resource allocation which performs optimization on a cellular automaton domain, applying suitable transition rules on the individual neighborhoods. Xuan et al. (2012) developed an optimal water allocation model based on water resources security assessment.

Fang et al. (2013) presented a comprehensive solution for water resources allocation in the Wuwei Basin and they concluded that the model can effectively balance the benefits among all regions and sections. Ward et al. (2013) provided a framework for identifying, designing, and implementing water allocation rules for food security in the 
developing world's irrigated areas. Kang and Park (2014) developed a combined simulation-optimization model for simulating reservoir operations by adopting the Shuffled Complex Evolution Method. They concluded that the model is useful for assessing reservoirs' irrigation water supply capacities when establishing operation plans and providing feasible alternatives for new operation rules. Salman et al. (2014) presented a methodology to maximize the net farm income in Iraq by producing different types of crops. Four water right (allocation) systems and three water supply scenarios were considered. The various conditions were compared in terms of their capacity to minimize losses in net farm water-related income. Fotakis and Sidiropoulos (2014) integrated land-use and water allocation planning to maximize economic benefit, while minimizing water extraction and transportation cost under ecological constraints. A review of agricultural irrigation water allocation optimization models using different programming for optimizing irrigation management was done by Singh (2014).

Vaghefi et al. (2015) linked the soil and water assessment tool (SWAT) to the generic river basin management decision support system (MODSIM) for water allocation in the Karkheh river basin. Their analyses indicate that it is possible to use changes in cropping patterns as an effective tool to adapt to the negative impacts of climate change. The optimization of water resources allocation in a typical river basin was proposed by Wang et al. (2015) using multi-objective programming. It was applied on the water deficient of Heihe River Basin by embedding land use as a constraint on water allocation. Their results demonstrate that the optimal program can predicate the actual situation of water allocation in the future. A multi-objective water allocation optimization model to maximize crop yields was developed by Lalehzari et al. 2015 .

Oxley et al. (2016) developed a model that defines the net economic benefits calculated in terms of both use and non-use values and sustainability in terms of the risks to water supplies and riverine ecological, environmental and hydrological integrity. An optimization model maximizing the sustainable net economic benefit over a long-term planning horizon was applied by Oxley and Mays (2016) to the Prescott Active Management Area. The model evaluates four scenarios to test the validity of the developed model and to provide examples of its potential application.

Nguyen et al. (2016A) developed an improved agricultural crop and water allocation model using ant colony optimization (ACO) by enabling the dynamic decision variable option (DDVO). The model maximizes the net benefit from allocating a fixed total volume of water to cultivated selected kinds of crops. Davijani et al. (2016) developed a water allocation optimization model using the particle swarm optimization (PSO) algorithm maximizes the number of the generated jobs in both agricultural and industrial sectors in the central desert region of Iran. The model gives water policy makers an indication about the optimal solution in case of certain policies to be adopted. Nguyen et al. (2016B) introduced a general optimization framework by optimizing crop and water allocation using ant colony optimization and dynamic decision variable option (ACO -DDVO). The model reduced search space size and increasing the computational efficiency of evolutionary algorithm application. Abdulbaki et al. (2017) developed an integer linear programming decision support model to optimally allocate water resources by minimizing water treatment, allocation, and environmental costs. The model has the flexibility to consider multiple water sources (seawater, surface water, groundwater and reclaimed wastewater) that allocated to different consumers (irrigation, potable, and industrial) with different quality requirements.

A genetic simulation-optimization framework for optimal irrigation and fertilizer scheduling was developed by Nguyen et al. (2017) using ant colony optimization (ACO). Anwar and Haq (2013) presented a GA to solve sequential irrigation scheduling problems. Four different consecutive irrigation scenarios were adopted using four GA models allocating irrigation water to 94 users.

An agricultural irrigation water allocation optimization model using a GA was developed to be applied on the Sri Ram Sagar project in India (Raju \& Kumar, 2004). Kumar et al. (2006) presented a water allocation optimization model for agricultural irrigation using GA. The model maximizes the net benefit from the use of certain types of crops following cropping pattern in Karnataka, India. Sadati et al. (2014) presented a nonlinear programming optimization model using a GA to maximize farm income by determining optimal reservoirs release and optimal cropping pattern.

Aljanabi et al. (2018) developed a nonlinear water allocation optimization model to maximize the net farm income from the cultivation of different types of crops irrigated by the Tigris and the Euphrates Rivers in Iraq. The model examines how profitability, at both the farm and basin levels, is affected by various water appropriation systems. 


\section{The Mathematical Model}

\subsection{Objective Function}

The objective function of this model is to maximize the total net benefit by comparing the results of using three different qualities of reclaimed wastewater, RW type A, type $B$, and type $C$, to irrigate farms $(x=1$ to $X$ ) cultivating crops ( $\mathrm{c}=1$ to $\mathrm{C}$ ). The model also assumes a proportional water sharing rule (PSR) to allocate RW among observed farmlands proportionally by considering the ratio of the observed farm's area in the entire system to the total farms' observed area. Each $\mathrm{RW}_{\mathrm{i}}$ irrigates certain types of crops depending on the quality requirements of that crop. The model computes the net benefit $\mathrm{Nb}_{\mathrm{i}}(\$)$ from the use of $\mathrm{RW}_{\mathrm{i}}$ by allowing only one crop $\mathrm{c}$ to be cultivated in each farm $x$ using the PSR. The objective function maximizes net benefits is:

$$
\operatorname{Max} . N b_{i}=\sum_{x} N b_{i, x} \quad \mathrm{i}=1, \ldots ., \mathrm{I}
$$

Where $\mathrm{Nb}_{\mathrm{i}, \mathrm{x}}$ represents the computed net benefit (\$) for each farm $\mathrm{x}$ cultivating crop c using RW type i. In general, the net benefit is usually computed by subtracting the cost of production from the selling price.

The total cost $\mathrm{CP}_{\mathrm{i}, \mathrm{x}, \mathrm{c}}(\$)$ to produce crop c cultivated in farm $\mathrm{x}$ using RW type $\mathrm{i}$ is the sum of crop's production cost plus the cost of the assigned RW type i to cultivate crop c, which is:

$$
C P_{i, x, c}=\sum_{c}\left(F A_{i, x, c} \operatorname{CCost}_{c}+R W_{i, x, c} R W C_{i}\right) \quad \mathrm{x}=1, \ldots ., \mathrm{X} \text { and } \mathrm{i}=1, \ldots ., \mathrm{I}
$$

Where $\mathrm{FA}_{\mathrm{i}, \mathrm{x}, \mathrm{c}}$ is the assigned area (ha) of farm $\mathrm{x}$ in hectare to cultivate crop c using RW type $\mathrm{i}$; CCost $_{\mathrm{c}}$ is crop $\mathrm{c}$ production cost $(\$ / h a) ; \mathrm{RW}_{\mathrm{i}, \mathrm{x}, \mathrm{c}}$ is the assigned $\mathrm{RW}\left(\mathrm{m}^{3}\right)$ of type $\mathrm{i}$ to irrigate farm $\mathrm{x}$ cultivating crop c; and $\mathrm{RWC}_{\mathrm{i}}$ is the cost $\left(\$ / \mathrm{m}^{3}\right)$ of $\mathrm{RW}$ type $\mathrm{i}$.

A crop's production cost is based on updated data including the cost of seeds, land preparation cost, labor cost, and fertilizer cost. A crop's yield is computed by considering the yield of each crop $Y_{c}$ (ton/ha) multiplied by the selling price of that crop $\mathrm{P}_{\mathrm{c}}\left(\$ /\right.$ ton) times the cultivated area $\mathrm{FA}_{\mathrm{i}, \mathrm{x}, \mathrm{c}}$ (ha), which is as follows:

$$
R e_{i, x, c}=Y_{c} P_{c} F A_{i, x, c}
$$

By re-arranging equations (2) and (3), the net benefit, $\mathrm{Nb}_{\mathrm{i}, \mathrm{x}, \mathrm{c}}$, of cultivating crop $\mathrm{c}$ in farm $\mathrm{x}$ using $\mathrm{RW}$ type $\mathrm{i}$ is:

$$
N b_{i, x, c}=\left(Y_{c} P_{c} F A_{i, x, c}\right)-\left(F A_{i, x, c} \operatorname{CCost}_{c}\right)-\left(R W_{i, x, c} R W C_{i}\right) \quad \mathrm{c}=1, \ldots, \mathrm{C}, \mathrm{x}=1, \ldots ., \mathrm{X} \text { and } \mathrm{i}=1, \ldots ., \mathrm{I}
$$

For any RW type i, assuming that each crop c has a coefficient of connectivity, $\mathrm{CRw}_{\mathrm{i}, \mathrm{c}}$, according to the crop's quality standards and salinity tolerance. Then, equation (4) can be re-written as:

$$
\begin{gathered}
N b_{i, x, c}=\left(Y_{c} P_{c} F A_{i, x, c} C R w_{i, c}\right)-\left(F A_{i, x, c} C \operatorname{Cost}_{c} C R w_{i, c}\right)-\left(R W_{i, x, c} R W C_{i} C R w_{i, c}\right) \\
\mathrm{c}=1, \ldots ., \mathrm{C}, \mathrm{x}=1, \ldots ., \mathrm{X} \text { and } \mathrm{i}=1, \ldots ., \mathrm{I}
\end{gathered}
$$

In this water allocation system, for any farm $\mathrm{x}$, there is only one crop $\mathrm{c}$ that can be cultivated using RW type i. By considering the connectivity coefficient $\mathrm{M}_{\mathrm{i}, \mathrm{x}, \mathrm{c}}$ of crop $\mathrm{c}$ to farm $\mathrm{x}$ and RW type $\mathrm{i}$ as a binary variable, the net benefit $\mathrm{Nb}_{\mathrm{i}, \mathrm{x}, \mathrm{c}}$ from the cultivation of crop $\mathrm{c}$ in farm $\mathrm{x}$ using $\mathrm{RW}$ type $\mathrm{i}$ can be re-written as:

$$
\begin{gathered}
N b_{i, x, c}=\left(Y_{c} P_{c} F A_{i, x, c} M_{i, x, c} C R w_{i, c}\right)-\left[\left(R W_{i, x, c} R W C_{i} M_{i, x, c} C R w_{i, c}\right)+\left(F A_{i, x, c} C \operatorname{Cost} M_{c} M_{i, x, c} C R w_{i, c}\right)\right] \\
\mathrm{c}=1, \ldots, \mathrm{C}, \mathrm{x}=1, \ldots, \mathrm{X} \text { and i }=1, \ldots ., \mathrm{I}
\end{gathered}
$$

To compute the net benefit $\mathrm{Nb}_{\mathrm{i}, \mathrm{x}}$ of cultivating farm $\mathrm{x}$ using RW type $\mathrm{i}$, the total net benefit equation is written as:

$$
N b_{i, x}=\sum_{c}\left[\left(Y_{c} P_{c} F A_{i, x, c} M_{i, x, c} C R w_{i, c}\right)-\left[\left(R W_{i, x, c} R W C_{i} M_{i, x, c} C R w_{i, c}\right)+\left(F A_{i, x, c} C \operatorname{Cost}_{c} M_{i, x, c} C R w_{i, c}\right)\right]\right]
$$

\subsection{Decision Variables}

$$
x=1, \ldots, X \text { and } i=1, \ldots ., I
$$

The optimization model allocates farmland areas and RW to cultivate different types of crops, so the decision variables are:

a) $\mathrm{FA}_{\mathrm{i}, \mathrm{x}, \mathrm{c}}$ assigned area of farm $\mathrm{x}$ to cultivate crop $\mathrm{c}$ using $\mathrm{RW}$ type $\mathrm{i}(\mathrm{ha})$

b) $\mathrm{RW}_{\mathrm{i}, \mathrm{x}, \mathrm{c}}$ assigned $\mathrm{RW}$ of type $\mathrm{i}$ to farm $\mathrm{x}$ farming crop $\mathrm{c}\left(\mathrm{m}^{3}\right)$

c) $\mathrm{M}_{\mathrm{i}, \mathrm{x}, \mathrm{c}}$ connectivity of RW type $\mathrm{i}$ to farm $\mathrm{x}$ and crop c (binary variable)

\subsection{Constraints}

Whenever a given amount of RW from a certain type $\mathrm{i}$ is allocated to irrigate crop c, it is important to optimally be allocated by considering the season of growth water requirements to satisfy a crop's real water consumption. Adopting this strategy will produce a reasonable irrigation scheme which reflects positively on crop yield and on 
the conservation of the consumed water to irrigate more lands. The available amount of RW type i should optimally be allocated to irrigate part or all of the observed farmlands considering the following constraints:

\subsubsection{RW Availability Constraints}

Three RW availabilities related to their quality are considered. The availability of RW type A ( $\mathrm{i}=1$ ) from tertiary treated wastewater; availability of RW type B (i=2) from secondary treated wastewater; and availability of RW type $\mathrm{C}(\mathrm{i}=3)$ from primary treated wastewater.

1) Consumed RW type $\mathrm{i}$

The sum of the total use of RW $\left(\mathrm{RW}_{\mathrm{i}, \mathrm{x}, \mathrm{c}}\right)$ of a certain type $\mathrm{i}$ must be equal or less than the total amount of RW $\left(\mathrm{QRw}_{\mathrm{i}}\right)$ of the same type i released from the same WWTP in the same cultivation season.

$$
\sum_{x} \sum_{c} R W_{i, x, c} \leq Q R w_{i} \quad \mathrm{i}=1, \ldots, \mathrm{I}
$$

Where $\mathrm{QRw}_{\mathrm{i}}$ is the total amount of assigned RW type $\mathrm{i}\left(\mathrm{m}^{3}\right)$.

2) Consumed RW by type $i$ and farm $x$

The sum of the assigned RW type $\mathrm{i}$ to irrigate farms $(\mathrm{x}=1$ to $\mathrm{X})$ cultivating crops ( $\mathrm{c}=1$ to $\mathrm{C})$ must be equal or less than the hydraulic loading $\mathrm{Lw}_{\mathrm{c}}\left(\mathrm{m}^{3} / \mathrm{ha}\right)$ of each crop c times the cultivated area $\mathrm{FA}_{\mathrm{i}, \mathrm{x}, \mathrm{c}}$ (ha), which is:

$$
\sum_{c} R W_{i, x, c}=\sum_{c} L w_{c} F A_{i, x, c} \quad \mathrm{x}=1, \ldots, \mathrm{X} \text { and } \mathrm{i}=1, \ldots, \mathrm{I}
$$

By applying RW-farm-crop connectivity coefficient $\left(\mathrm{M}_{\mathrm{i}, \mathrm{x}, \mathrm{c}}\right)$ and $\mathrm{RW}$-crop coefficient $\left(\mathrm{CRw}_{\mathrm{i}, \mathrm{c}}\right)$ on both sides of equation (9), it yields to:

$$
\sum_{c} R W_{i, x, c} M_{i, x, c} C R w_{i, c}=\sum_{c} L w_{c} F A_{i, x, c} M_{i, x, c} C R w_{i, c} \quad \mathrm{x}=1, \ldots, \mathrm{X} \text { and } \mathrm{i}=1, \ldots, \mathrm{I}
$$

The hydraulic loading $\mathrm{Lw}_{\mathrm{c}}\left(\mathrm{m}^{3} / \mathrm{ha}\right)$ considering each cultivated crop c is computed as:

$$
L w_{c}=\frac{N R_{C}}{\frac{E_{C}}{100}}\left(\frac{10000}{1000}\right)=E T c_{k, j} \times\left(1+\frac{L R_{c}}{100}\right) \times\left(\frac{100}{E_{c}}\right)\left(\frac{10000}{1000}\right) \quad \mathrm{c}=1, \ldots, \mathrm{C}
$$

Where $\mathrm{ETc}_{\mathrm{c}}$ is the evapotranspiration requirements ( $\left.\mathrm{mm} / \mathrm{season}\right)$ to cultivate crop $\mathrm{c} ; \mathrm{E}_{\mathrm{c}}$ is the irrigation efficiency to cultivate crop $\mathrm{c} ; \mathrm{NR}_{\mathrm{c}}$ is the net irrigation requirements $(\mathrm{mm} / \mathrm{season})$ to cultivate crop $\mathrm{c}$; $\mathrm{LR}_{\mathrm{c}}$ is the leaching requirement to cultivate crop c; and (10000/1000) is a conversion factor to $\mathrm{m}^{3} / \mathrm{ha}$.

3) Consumed RW from source $\mathrm{i}$ by farm $\mathrm{x}$ irrigating crop c

$$
\sum_{c} R W_{i, x, c}=R L n_{i, x} Q R w_{i} \quad \mathrm{x}=1, \ldots, \mathrm{X} \text { and } \mathrm{i}=1, \ldots, \mathrm{I}
$$

By applying RW-farm-crop connectivity coefficient $\left(\mathrm{M}_{\mathrm{i}, \mathrm{x}, \mathrm{c}}\right)$ and $\mathrm{RW}$-crop coefficient $\left(\mathrm{CRw}_{\mathrm{i}, \mathrm{c}}\right)$ on both sides of equation (12), it yields to:

$$
\sum_{c} R W_{i, x, c} M_{i, x, c} C R w_{i, c}=R L n_{i, x} Q R w_{i} \quad \mathrm{x}=1, \ldots, \mathrm{X} \text { and } \mathrm{i}=1, \ldots, \mathrm{I}
$$

where $R \operatorname{Ln} n_{i, x}$ is the ratio of the observed area of farm $x\left(\operatorname{Ln}_{x}\right)$ to the total observed area in the system $\left(T L n_{i}\right)$, defined as:

$$
R L n_{i, x}=L n_{x} / T L n_{i} \quad \mathrm{x}=1, \ldots, \mathrm{X} \text { and } \mathrm{i}=1, \ldots, \mathrm{I}
$$

Equation (13) assures the proportionality in water allocation among farmlands considering the ratio of their areas in the system.

\subsubsection{Irrigated Farmlands Constraints}

1) Irrigated area of farm $x$

The area in production $\mathrm{FA}_{\mathrm{i}, \mathrm{x}, \mathrm{c}}$ (ha) of farm $\mathrm{x}$ cultivating crop c using $\mathrm{RW}$ type $\mathrm{i}$ must be equal or less than the observed area $\operatorname{Ln}_{\mathrm{x}}$ (ha) of farm $\mathrm{x}$, as:

$$
\sum_{c} F A_{i, x, c} \leq L n_{x} \quad \mathrm{x}=1, \ldots, \mathrm{X} \text { and } \mathrm{i}=1, \ldots, \mathrm{I}
$$

By applying $\mathrm{RW}$-crop coefficient $\left(\mathrm{CRw}_{\mathrm{I}, \mathrm{c}}\right)$ in equation (15), it yields to:

$$
\sum_{c} F A_{i, x, c} C R w_{i, c} \leq L n_{x} \quad \mathrm{x}=1, \ldots, \mathrm{X} \text { and } \mathrm{i}=1, \ldots, \mathrm{I}
$$

2) Total irrigated farmlands area per RW type $i$

The sum of the total irrigated area in the system must be equal or less than the area of the total observed farmlands, which is: 


$$
\sum_{x} \sum_{c} F A_{i, x, c} \leq \sum_{x} L n_{x} \quad \mathrm{i}=1, \ldots ., \mathrm{I}
$$

3) Maximum farmlands area to be cultivated by crop c

In order not to exceed the upper limit of the area cultivated using crop c to avoid the domination of the most economic crop on others and to force the model to select as many crops as it could to satisfy the variety in production, the following constraint is considered:

$$
\sum_{x} F A_{i, x, c} \leq F A R W C_{i, c} \quad \mathrm{i}=1, \ldots, \mathrm{I} \text { and } \mathrm{c}=1, \ldots, \mathrm{C}
$$

where $\mathrm{FARWC}_{\mathrm{i}, \mathrm{c}}$ is the maximum area (ha) allowed to be cultivated with crop c using RW type $\mathrm{i}$.

\subsubsection{Connectivity of RW Type i to Farm x and Crop c Constraint}

This binary variable coefficient $\mathrm{M}_{\mathrm{i}, \mathrm{x}, \mathrm{c}}$ assures that only one crop $\mathrm{c}$ is to be cultivated in farm $\mathrm{x}$ irrigated using RW type i. So, the sum of $\mathrm{M}_{\mathrm{i}, \mathrm{x}, \mathrm{c}}$, for the same farm $\mathrm{x}$ irrigated from the same RW type $\mathrm{i}$, must be equal to 1.0 , as in the following

\section{Baghdad as a Case Study}

$$
\sum_{i} \sum_{x} M_{i, x, c}=1 \quad \mathrm{c}=1, \ldots, \mathrm{C}
$$

The location of the wastewater treatment plant (RW source), locations and types of the potential RW uses, water quality consideration, the need for additional treatment, and the cost of competing for alternative sources are the main local conditions which influence the economics of RW reuse. Producing RW suitable for agricultural irrigation is less costly than to provide a higher level of treatment, such as nutrient removal, necessary for discharge into ecological sensitive surface waters (Metcalf et al., 2007).

Reuse of wastewater in Baghdad is logical as the wastewater treatment plants are located in the southern portion of Baghdad and there is land available for irrigation south of Baghdad. Furthermore, the RW can be delivered by gravity using mostly existing irrigation canals. Two wastewater treatment plants can treat a total of $1.0 \times 10^{6}$ $\mathrm{m}^{3} / \mathrm{d}$ by secondary treatment. The Alrustumia wastewater treatment can treat $5.5 \times 10^{5} \mathrm{~m}^{3} / \mathrm{d}$ in a three different treatment trains and this is the plant that is being considered for production of RW in this study. The total land available for irrigation that is being considered is 7,045 ha divided into 106 individual farms. Each farm is based on land ownership and are therefore of different land areas.

\section{Data for Optimization Model}

Crop water requirements ETc were adopted from Salman et al., (2014) and updated from the Strategy for Water and Land Resources in Iraq (MoWR, 2015). Crop production costs in US dollar per hectare (\$/ha), presented in Table 1, based on data secured from the Iraqi Ministry of Agriculture. The production cost includes soil fertility, weather, and water availability and quality which fluctuated across Iraq. The yield rates of different types of crops in Iraq are provided in Table 1.

There is a variety of 33 strategic crops which can be cultivated in Iraq (MoWR, 2015) which can be irrigated using $\mathrm{RW}$ as an alternative source considering its quality, crop type, and the irrigation method. Those crops can be divided into human edible and inedible crops in addition to the industrial crops. So, the optimization maximizes the net benefit of 14 crops of the 33 strategic crops to measure their profitability. Table 1 shows the strategic crops

\begin{tabular}{|c|c|c|c|c|c|c|c|c|c|c|c|c|c|c|}
\hline Crop & Cotton & Wheat & Maize & Potato & Tomato & Barley & Clover & Cucumber & Alfalfa & Onion & Eggplant & Sunflower & Sesame & Okra \\
\hline $\begin{array}{l}\text { Cost } \\
(\$ / h a)\end{array}$ & 1200 & 820 & 900 & 750 & 1300 & 720 & 320 & 1350 & 500 & 580 & 1250 & 550 & 475 & 1230 \\
\hline
\end{tabular}
which are adopted in the optimization model.

Table 1. Crop production costs exclusive of water costs (\$ US per ha)

In order to force the model not exceed a maximum area for each crop, maximum allowed areas were assigned to each crop for different types of RW (Table 2).

Table 2. Maximum allowed areas (ha) to be cultivated by certain types of crops irrigated using three RW qualities

\begin{tabular}{ccccccccccccccc}
\hline & Cotton & Wheat & Maize & Potato & Tomato & Barley & Clover & Cucumber & Alfalfa & Onion & Eggplant & Sunflower & Sesame & Okra \\
\hline $\mathrm{RW}_{\mathrm{A}}$ & 1500 & 1500 & 1500 & 1250 & 750 & 1500 & 1000 & 300 & 1000 & 300 & 250 & 1000 & 500 & 200 \\
$\mathrm{RW}_{\mathrm{B}}$ & 1500 & 2000 & 1500 & 0 & 750 & 1500 & 1000 & 300 & 1000 & 0 & 250 & 250 & 500 & 200 \\
$\mathrm{RW}_{\mathrm{C}}$ & 1500 & 0 & 0 & 0 & 0 & 1500 & 2000 & 0 & 2000 & 0 & 0 & 1500 & 0 & 0 \\
\hline
\end{tabular}

\section{Results and Discussion}

The results of the solution of the 0/1 mixed integer nonlinear programming (MINLP) optimization model are presented in Figures 2-4. The branch and reduce optimization navigator (BARON) solver (Tawarmalani \& 
Shahinidis, 2005) in the general algebraic modeling system (GAMS) (GAMS, 2017) was implemented. The net farm income was predicted by maximizing the net benefit by allocating RW type A, type B, and Type C to irrigate a variety of 14 strategic crops to be cultivated in 106 farms of 7045 (ha) in Baghdad under the use of proportional water sharing rule (PSR).

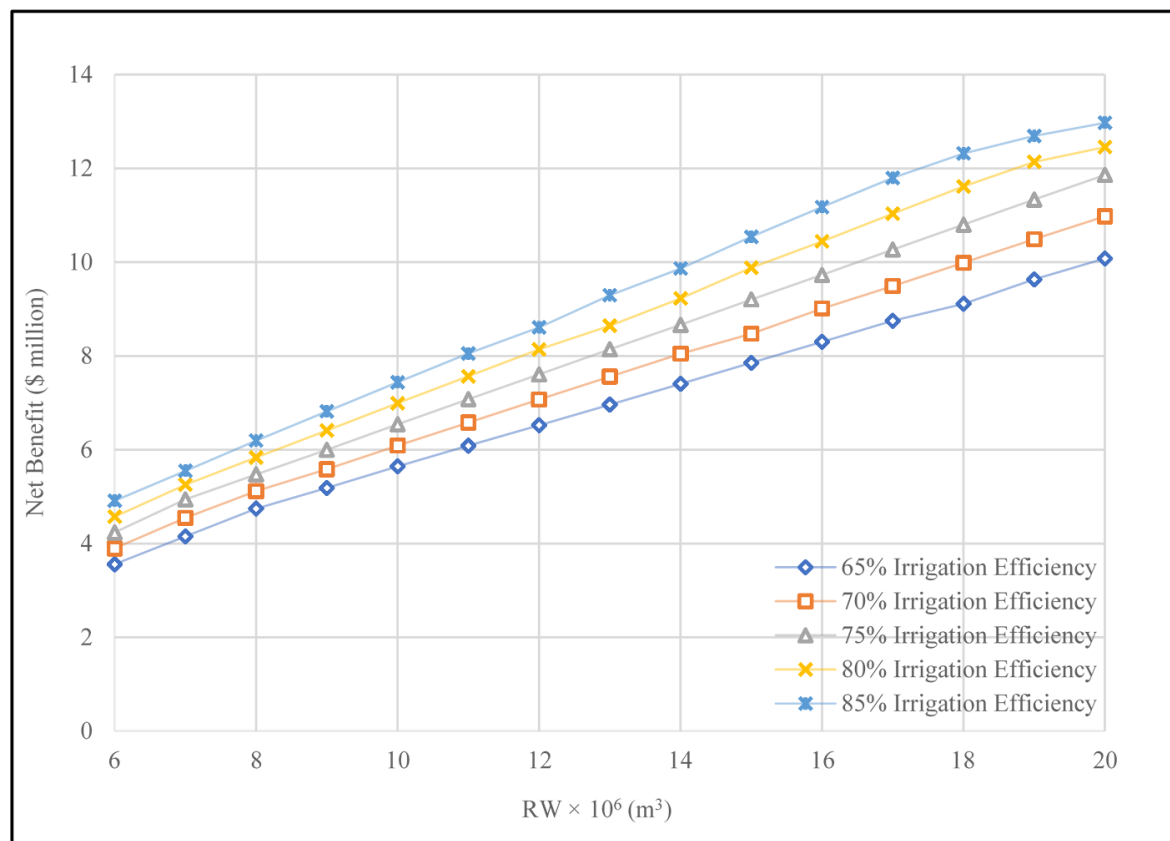

Figure 2. Computed net benefit (\$) comparing irrigation efficiencies using RW type A

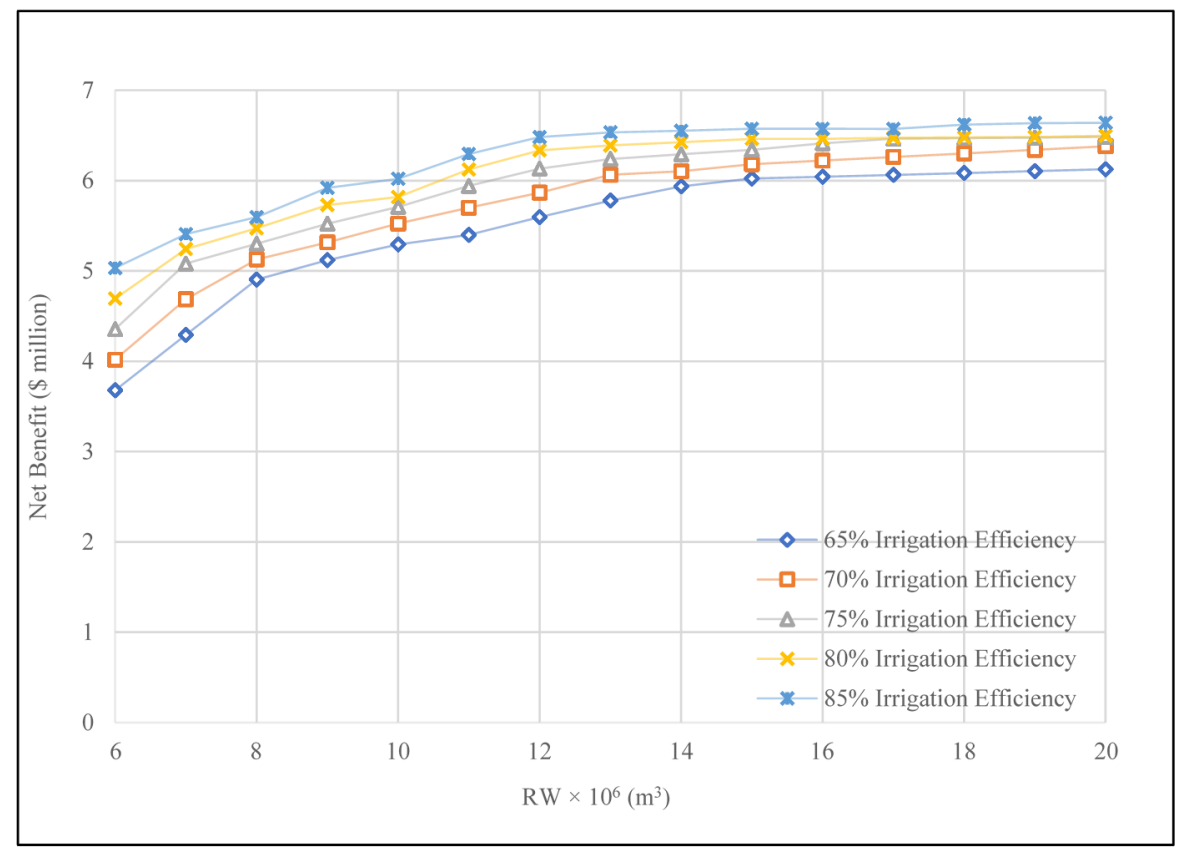

Figure 3. Computed net benefit (\$) comparing irrigation efficiencies using RW type B 


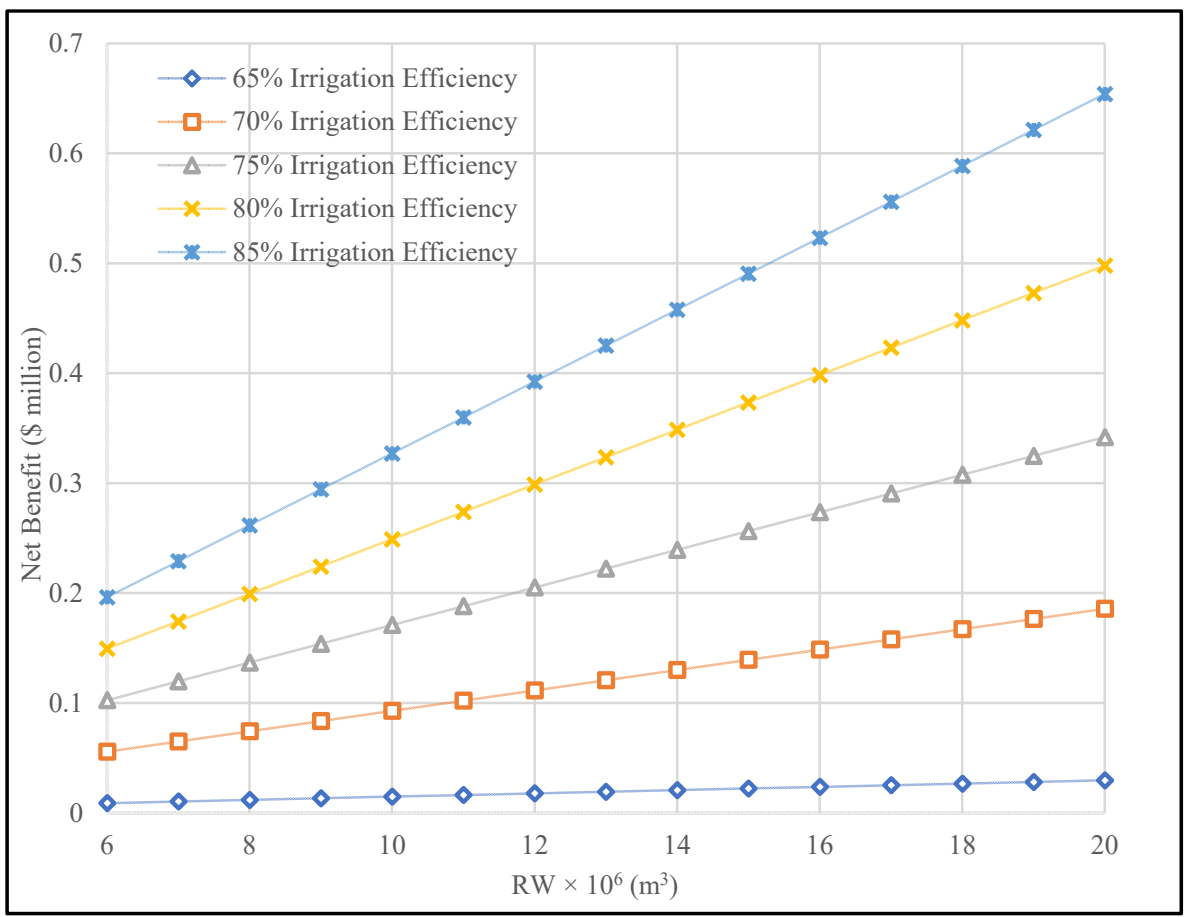

Figure 4. Computed net benefit (\$) comparing irrigation efficiencies using RW type C

The predicted net benefit results of using RW type A, type B, and type C respectively, under five different irrigation efficiencies are illustrated in Figures 2-4 respectively. It is obvious that the increase of irrigation efficiency reflects positively on the net income due to the decrease in the RW requirement which gives the opportunity to cultivate larger areas selecting the highest value crops.

As illustrated in Figure 2, the optimization model results show a consistent net benefit increase corresponding with the increase of irrigation efficiencies for most assumed quantities of RW type A because the crops which are selected by the model are close to each other in their net benefit. Using $6 \times 10^{6} \mathrm{~m}^{3}$ of RW type A and $65 \%$ irrigation efficiency, the predicted net benefit was $\$ 3.56 \times 10^{6}$ irrigating 556 ha of tomato. Using $20 \times 10^{6} \mathrm{~m}^{3}$ of RW type A and $85 \%$ irrigation efficiency, there was 1248 ha of potato, 747 ha of tomato, and 202 ha of onion with a predicted net benefit of about $\$ 13.0 \times 10^{6}$.

RW type B shows a slightly different behavior (Figure 3) because it has a lower range of crops to be cultivated which reduces the maximized net benefit. The crops which were computed by the model to be irrigated using RW type $B$ above the level of $12 \times 10^{6} \mathrm{~m}^{3}$ have a lower marginal net benefit than okra, eggplant, and cucumber. Using $6 \times 10^{6} \mathrm{~m}^{3}$ of RW type B and $65 \%$ irrigation efficiency predicted a net benefit of $\$ 3.68 \times 10^{6}$ irrigating 556 ha of tomato. In comparison, there were 748 ha of tomato, 248 ha of eggplant, 200 ha of okra, 298 ha of cucumber, and 530 ha of clover resulting in a $\$ 6.64 \times 10^{6}$ net benefit.

$\mathrm{RW}$ type $\mathrm{C}$ maintained the same trend with the maximized net benefit (Figure 4) because it can only irrigate a small selection of crops. Using $6 \times 10^{6} \mathrm{~m}^{3}$ of RW type $\mathrm{C}$ and $65 \%$ irrigation efficiency, the model irrigated 556 ha of clover. When the model used $20 \times 10^{6} \mathrm{~m}^{3}$ of RW type $\mathrm{C}$ with $85 \%$ irrigation efficiency, only 1551 ha of clover was irrigated. This is because clover is one of the highest water demand crops among the selected list of crops (Table 2) but it has the highest net benefit per hectare.

In this model, RW type A can select from all the 14 strategic crops, RW type B and RW type C are capable of selecting 12 and 5 crops, respectively, of the 14 selected crops shown in Table 2. On the other hand, each crop has its own evapotranspiration, production cost, yield, and selling price, which causes the variation in the predicted farms economic benefits. For instance, the predicted benefit of using $14 \times 10^{6} \mathrm{~m}^{3}$ of RW type A adopting $80 \%$ irrigation efficiency is about $\$ 9.23 \times 10^{6}$ cultivating a total of 1499 ha farming 736 ha of tomato and 763 ha of potato. The model predicted the net benefit of using the same amount of RW type B under the same irrigation efficiency is about $\$ 6.43 \times 10^{6}$ cultivating 750 ha of tomatoes, 285 ha of cucumber, 250 ha of eggplant, 177 ha of okra, and 30 ha of clover. While the net benefit is predicted to be $\$ 3.49 \times 10^{6}$ using RW type C irrigating 1022 ha of clover. It is obvious that the use of RW type $\mathrm{C}$ provide the lowest net benefit due to the limited number of crops 
which are irrigated, due to quality standards, and the low marginal benefit of those crops in comparison to RW types A and B.

The results show that RW type A provides the highest net benefit of RW to be used since it allowed for irrigation of crops with the highest net benefit. The capability of RW type A to irrigate all the suggested crops, due its high quality, has promoted the model the opportunity of selecting the high value crops for cultivation. A similar phenomenon is observed under the use of RW type B where it has fewer options for crops to be cultivated as compared to RW type A.

Figures 5-9 compare the net benefit from the use of RW types A, B and C under $65 \%, 70 \%, 75 \%, 80 \%$ and $85 \%$ irrigation efficiencies respectively. Figure 5 shows that using $6 \times 10^{6}$ to $8.5 \times 10^{6} \mathrm{~m}^{3}$ availability of reclaimed wastewater, RW type B performs better than RW types A and C. This domination of RW type B over RW type A is because the model selected the same type of crop, which is tomato, to be cultivated in same areas using RW type $\mathrm{A}$ and $\mathrm{B}$, but the difference occurred because the cost of RW type $\mathrm{B}$ is less than RW type A. The domination of RW type B on RW type A decreases with the increase in RW volumes, as the model allocates water on farmlands to cultivate the most economic crop (Figures 8 and 9). For instance, under a certain amount of RW availability, the model selected tomatoes and then potatoes to be cultivated using RW type A, while tomato, cucumber, eggplant and okra were selected to be irrigated by RW type B.

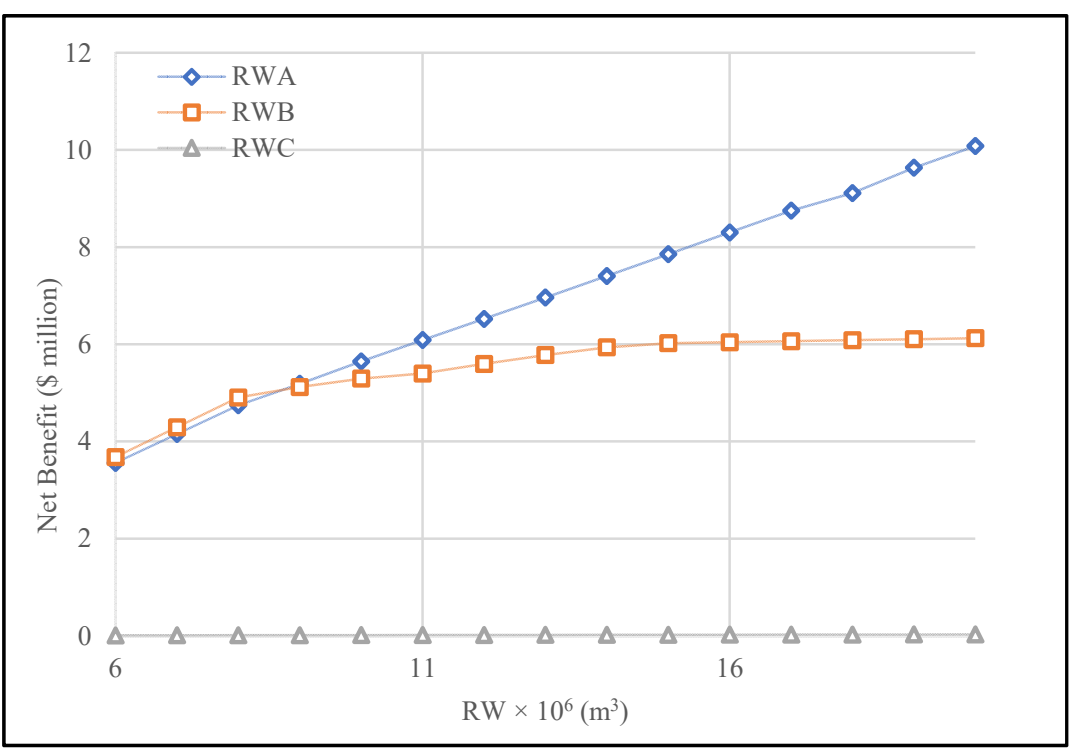

Figure 5. Computed net benefit (\$) adopting 65\% irrigation efficiency

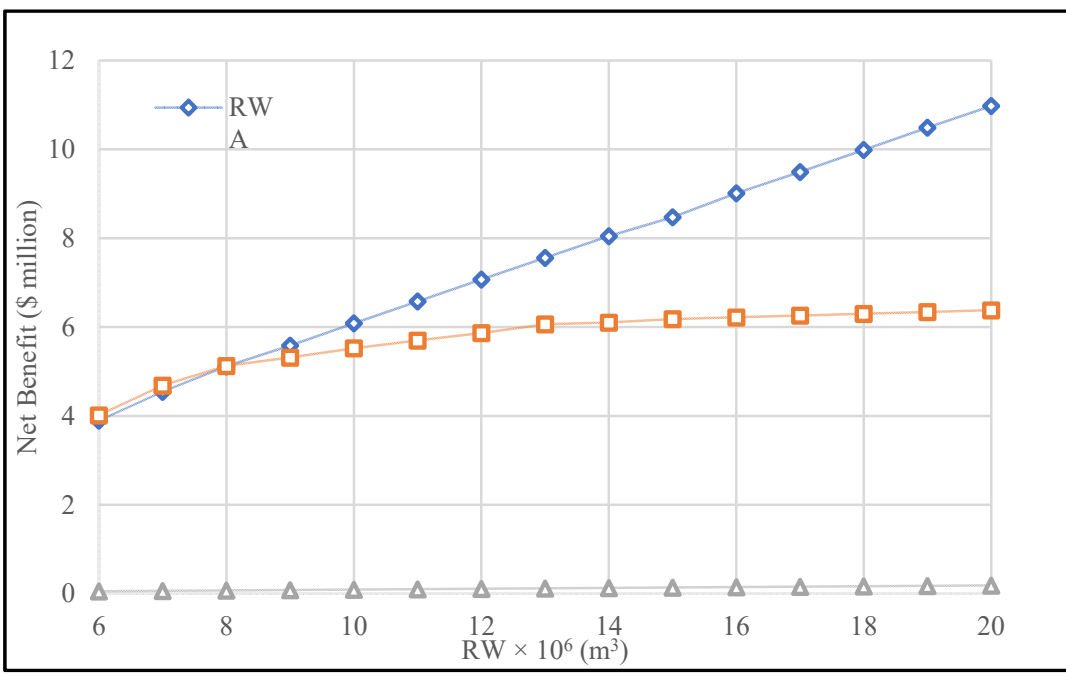

Figure 6. Computed net benefit (\$) adopting 70\% irrigation efficiency 


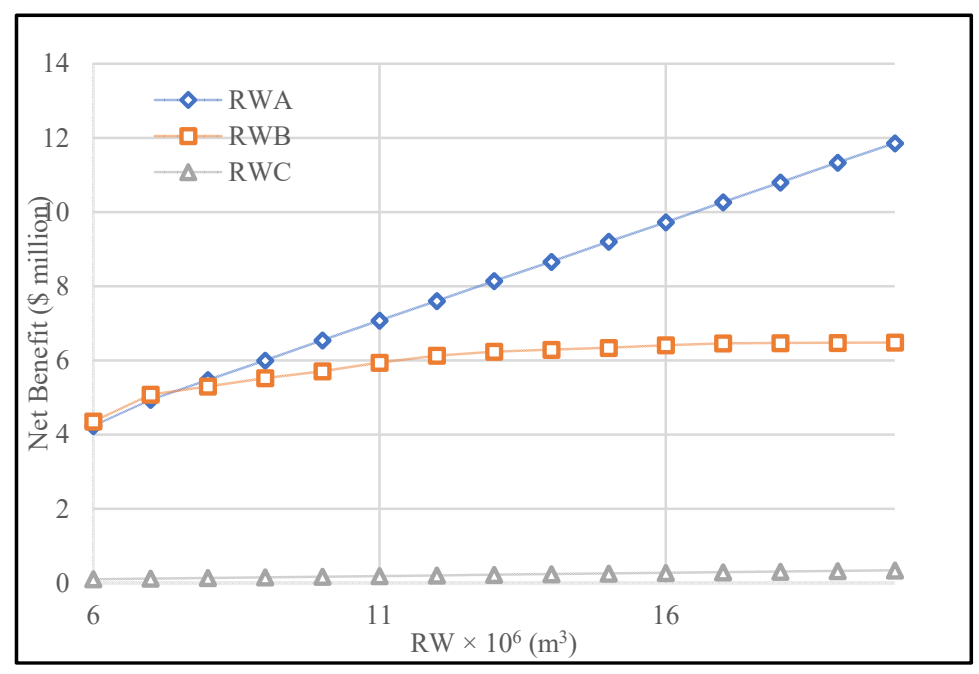

Figure 7. Computed net benefit (\$) adopting 75\% irrigation efficiency

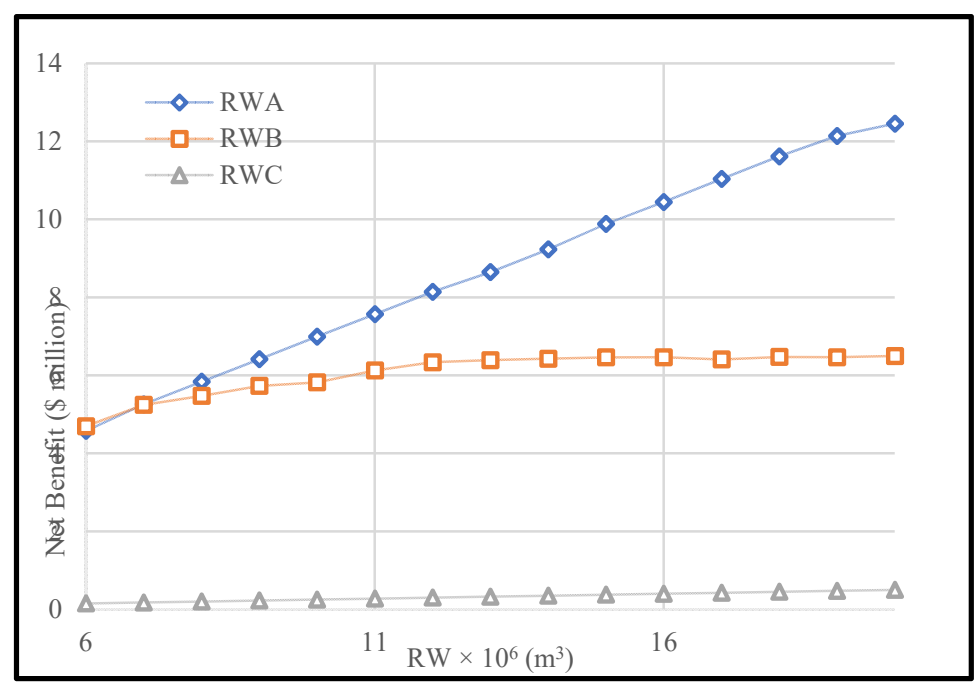

Figure 8. Computed net benefit (\$) adopting 80\% irrigation efficiency

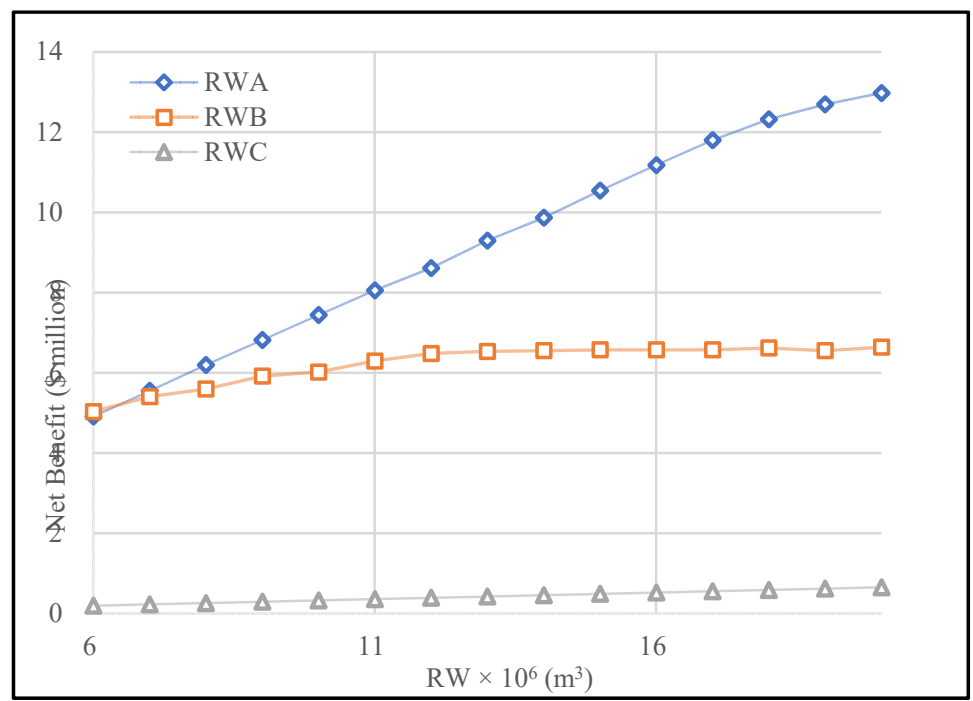

Figure 9. Computed net benefit (\$) adopting $85 \%$ irrigation efficiency 


\section{Summary}

The positive results from comparing the use of different RW qualities under different irrigation efficiencies helps in the evaluation of the Alrustumia WWTP, and others in Iraq, to show how it is efficient to invest in treated wastewater for agricultural irrigation instead of deposition to the environment. On the other hand, this study helps the decision makers take advantage of promoting wastewater treatment efficiencies of the recently rebuilt WWTPs by considering tertiary treatment for the existing and potential new WWTPs to employ their reclaimed wastewater for agricultural irrigation or other practices. In addition, the available wide range of selected crops considering RW type A offered the model a flexibility in selecting the highest economic crops to satisfy the maximum limit of the allowable cultivated area by each crop.

\section{Acknowledgements}

Special thanks and gratitude to the Ministry of Higher Education and Scientific Researches-Iraq for the sponsoring and funding Ahmed A. Aljanabi's graduate study at Arizona State University.

\section{References}

Abdulbaki, D., Al-Hindi, M., Yassine, A., \& Najm, M. A. (2017). An optimization model for the allocation of water resources. Journal of Cleaner Production, 164, 994-1006. https://doi.org/10.1016/j.jclepro.2017. 07.024

Al-Ansari, N. (2013). Management of water resources in Iraq: perspectives and prognoses. Engineering, 5(6), 667-684. https://doi.org/10.4236/eng.2013.58080

Al-Ansari, N., Knutsson, S., \& Ali, A. (2012). Restoring the garden of Eden, Iraq. Journal of Earth Sciences and Geotechnical Engineering, 2(1), 53-88.

Aljanabi, A. A., Mays, L. W., \& Fox, P. (2018). Application of an optimization model for assessing the performance of water appropriation in Iraq. Environment and Natural Resources Research, 8(1), 105. https://doi.org/10.5539/enrr.v8n1p105

Alvarez, J. F. O., de Juan Valero, J. A., Martín-Benito, J. M. T., \& Mata, E. L. (2004). MOPECO: an economic optimization model for irrigation water management. Irrigation Science, 23(2), 61-75. https://doi.org/10.1007/s00271-004-0094-x

Anwar, A. A., \& Haq, Z. U. (2013). Genetic algorithms for the sequential irrigation scheduling problem. Irrigation Science, 31(4), 815-829. https://doi.org/10.1007/s00271-012-0364-y

Benetti, A. D. (2008). Water reuse: issues, technologies, and applications. Engenharia Sanitaria e Ambiental, 13(3), 247-248.

Brown, T., Diaz, G., \& Sveinsson, O. (2002). Planning water allocation in river basins aquarius: a system's approach. Presented at the Proceedings of 2nd Federal Interagency Hydrologic Modeling Conference, Subcommittee on Hydrology of the Advisory Committee on Water Information.

Burton, M. (1994). A simulation of water allocation policies in times of water shortage. Irrigation and Drainage Systems, 8(2), 61-81. https://doi.org/10.1007/BF00881176

Davijani, M. H., Banihabib, M., Anvar, A. N., \& Hashemi, S. (2016). Optimization model for the allocation of water resources based on the maximization of employment in the agriculture and industry sectors. Journal of Hydrology, 533, 430-438. https://doi.org/10.1016/j.jhydrol.2015.12.025

Evans, R., \& Sadler. J., (2008). Methods and technologies to improve efficiency of water use. Water Resources Research, 44(7), N/a. https://doi.org/10.1029/2007WR006200

Fang, S., Guo, P., Li, M., \& Zhang, L. (2013). Bilevel multiobjective programming applied to water resources allocation. Mathematical Problems in Engineering, 2013. http://dx.doi.org/10.1155/2013/837919

FAO. 2016. AQUASTAT website. Food and Agriculture Organization of the United Nations (FAO). Website accessed on [2017/03/15].

Fotakis, D., \& Sidiropoulos, E. (2012). A new multi-objective self-organizing optimization algorithm (MOSOA) for spatial optimization problems. Applied Mathematics and Computation, 218(9), 5168-5180. https://doi.org/10.1016/j.amc.2011.11.003

Fotakis, D., \& Sidiropoulos, E. (2014). Combined land-use and water allocation planning. Annals of Operations Research, 219(1), 169-185. https://doi.org/10.1007/s10479-012-1080-y

GAMS Development Corporation (2013). General algebraic modeling system (GAMS), Release 24.2.1. Washington, DC, USA, 2013. 
Iraqi Central Statistical Organization (ICSO). (2017). http://cosit.gov.iq/ar/agri-stat/ veg-prod

Ghahraman, B., \& Sepaskhah, A. (2004). Linear and non-linear optimization models for allocation of a limited water supply. Irrigation and Drainage, 53(1), 39-54. https://doi.org/10.1002/ird.108

Georgiou, P., \& Papamichail, D. (2008). Optimization model of an irrigation reservoir for water allocation and crop planning under various weather conditions. Irrigation Science, 26(6), 487-504. https://doi.org/10. 1007/s00271-008-0110-7

Haq, Z. U., \& Anwar, A. A. (2010). Irrigation scheduling with genetic algorithms. Journal of Irrigation and Drainage Engineering, 136(10), 704-714. https://doi.org/10.1061/(ASCE)IR.1943-4774.0000238

Haq, Z. U., Anwar, A. A., \& Clarke, D. (2008). Evaluation of a genetic algorithm for the irrigation scheduling problem. Journal of Irrigation and Drainage Engineering, 134(6), 737-744. https://doi.org/10.1061/(ASCE) 0733-9437(2008)134:6(737)

Kang, M. G., \& Park, S. W. (2014). Combined simulation-optimization model for assessing irrigation water supply capacities of reservoirs. Journal of Irrigation and Drainage Engineering, 140(5), 04014005. https://doi.org/10.1061/(ASCE)IR.1943-4774.0000726

Lalehzari, R., Boroomand Nasab, S., Moazed, H., \& Haghighi, A. (2015). Multiobjective management of water allocation to sustainable irrigation planning and optimal cropping pattern. Journal of Irrigation and Drainage Engineering, 142(1), 05015008. https://doi.org/10.1061/(ASCE)IR.1943-4774.0000933

Lu, H., Huang, G., \& He, L. (2011). An inexact rough-interval fuzzy linear programming method for generating conjunctive water-allocation strategies to agricultural irrigation systems. Applied Mathematical Modelling, 35(9), 4330-4340. https://doi.org/10.1016/j.apm.2011.03.008

Metcalf, E., Asano, T., Burton, F., Leverenz, H., Tsuchihashi, R., \& Tchobanoglous, G. (2007). Water Reuse: Issues, Technologies, and Applications.

Ministry of Water Resources-Iraq (2015). Strategy for water and land resources in Iraq (SWLRI). A study done on behalf of the Iraqi Ministry of Water Resources, 2015.

Moradi-Jalal, M., Haddad, O. B., Karney, B. W., \& Marino, M. A. (2007). Reservoir operation in assigning optimal multi-crop irrigation areas. Agricultural Water Management, 90(1-2), 149-159. https://doi.org/10.1016/j.agwat.2007.02.013

Naadimuthu, G., Raju, K., \& Lee, E. (1999). A heuristic dynamic optimization algorithm for irrigation scheduling. Mathematical and Computer Modelling, 30(7-8), 169-183. https://doi.org/10.1016/S0895-7177 (99)001727

Kumar, D., Raju, K. S., \& Ashok, B. (2006). Optimal reservoir operation for irrigation of multiple crops using genetic algorithms. Journal of Irrigation and Drainage Engineering, 132(2), 123-129.

Nguyen, D. C. H., Ascough II, J. C., Maier, H. R., Dandy, G. C., \& Andales, A. A. (2017). Optimization of irrigation scheduling using ant colony algorithms and an advanced cropping system model. Environmental Modelling \& Software, 97, 32-45. https://doi.org/10.1016/j.envsoft.2017.07.002

Nguyen, D. C. H., Maier, H. R., Dandy, G. C., \& Ascough II, J. C. (2016B). Framework for computationally efficient optimal crop and water allocation using ant colony optimization. Environmental Modelling \& Software, 76, 37-53. https://doi.org/10.1016/j.envsoft.2015.11.003

Nguyen, D., Dandy, G., Maier, H., \& Ascough, J. (2016A). Improved ant colony optimization for optimal crop and irrigation water allocation by incorporating domain knowledge. Journal of Water Resources Planning and Management, 142(9), 04016025. https://doi.org/10.1061/(ASCE)WR.1943-5452.0000662

Oxley, R. L., \& Mays, L. W. (2016). Application of an optimization model for the sustainable water resource management of river basins. Water Resources Management, 30(13), 4883-4898. https://doi.org/10.1007/ s11269-016-1459-7

Oxley, R. L., Mays, L. W., \& Murray, A. (2016). Optimization model for the sustainable water resource management of river basins. Water Resources Management, 30(9), 3247-3264. https://doi.org/10.1007/ s11269-016-1345-3

Paul, S., Panda, S. N., \& Kumar, D. N. (2000). Optimal irrigation allocation: a multilevel approach. Journal of Irrigation and Drainage Engineering, 126(3), 149-156. https://doi.org/10.1061/(ASCE)0733-9437(2000) 126:3(149) 
Raju, K. S., \& Kumar, D. N. (2004). Irrigation planning using genetic algorithms. Water Resources Management, 18(2), 163-176. https://doi.org/10.1023/B:WARM.0000024738.72486.b2

Rao, N., Sarma, P., \& Chander, S. (1988). Irrigation scheduling under a limited water supply. Agricultural Water Management, 15(2), 165-175. https://doi.org/10.1016/0378-3774(88)90109-6

Sadati, S. K., Speelman, S., Sabouhi, M., Gitizadeh, M., \& Ghahraman, B. (2014). Optimal irrigation water allocation using a genetic algorithm under various weather conditions. Water, 6(10), 3068-3084. DOI: $10.3390 /$ w6103068

Sadegh, M., Mahjouri, N., \& Kerachian, R. (2010). Optimal inter-basin water allocation using crisp and fuzzy Shapley games. Water Resources Management, 24(10), 2291-2310. https://doi.org/10.1007/s11269-009 9552-9

Salman, A., Al-Karablieh, E., \& Fisher, F. (2001). An inter-seasonal allocation of irrigation water system. Agric. Syst, 68, 233-252. https://doi.org/10.1016/S0308-521X(01)00010-5

Salman, D. A., Amer, S. A., \& Ward, F. A. (2014). Water appropriation systems for adapting to water shortages in Iraq. JAWRA Journal of the American Water Resources Association, 50(5), 1208-1225. https://doi.org/ 10.1111/jawr.12186

Seckler, D. W. (1998). World water demand and supply, 1990 to 2025: Scenarios and issues (Vol. 19). Iwmi.

Shangguan, Z., Shao, M., Horton, R., Lei, T., Qin, L., \& Ma, J. (2002). A model for regional optimal allocation of irrigation water resources under deficit irrigation and its applications. Agricultural Water Management, 52(2), 139-154. https://doi.org/10.1016/S0378-3774(01)00116-0

Shean, M. (2008). Iraq: drought reduces 2008/09 winter grain production. United States Department of Agriculture, Foreign Agricultural Service. May, 9. Retrieved from https:/ipad.fas.usda.gov/highlights/ 2008/05/Iraq may2008.htm

Tawarmalani, M. \& Shahinidis, N. V. (2005). A polyhedral branch-and-cut-approach to global optimization, Mathematical Programming, 103(2), 225-249, 2005. https://doi.org/10.1007/s10107-005-0581-8

UNDP (2009). UNDP Helps drought-stricken Iraq combat effects of climate change. United Nations Development Programme. Retrieved from http:/www.undp.org/content/undp/en/home/presscenter/articles/ 2009/12/16/undp-helps-drought-stricken-iraq-combat-effects-of-climate-change.html

Singh, A. (2014). Irrigation planning and management through optimization modelling. Water Resources Management, 28(1), 1-14. https://doi.org/10.1007/s11269-013-0469-y

Vaghefi, S. A., Mousavi, S., Abbaspour, K., Srinivasan, R., \& Arnold, J. (2015). Integration of hydrologic and water allocation models in basin-scale water resources management considering crop pattern and climate change: Karkheh River Basin in Iran. Regional Environmental Change, 15(3), 475-484. https://doi.org/10.1007/s10113-013-0573-9

Wang, Z., Yang, J., Deng, X., \& Lan, X. (2015). Optimal water resources allocation under the constraint of land use in the Heihe River Basin of China. Sustainability, 7(2), 1558-1575. DOI:10.3390/su7021558

Ward, F. A., Amer, S. A., \& Ziaee, F. (2013). Water allocation rules in Afghanistan for improved food security. Food Security, 5(1), 35-53. https://doi.org/10.1007/s12571-012-0224-X

World Bank, 2006. Iraq: Country water resources, assistance strategy: addressing major threats to people's livelihoods. Report No. 36297-IQ, 2006, p. 97.

Xuan, W., Quan, C., \& Shuyi, L. (2012). An optimal water allocation model based on water resources security assessment and its application in Zhangjiakou Region, northern China. Resources, Conservation and Recycling, 69, 57-65. https://doi.org/10.1016/j.resconrec.2012.09.005

You, J., Gan, Z., Gan, H., \& Jia, L. (2011). Development and application of water allocation model based on ETcontrol. IAHS-AISH Publication, 198-205.

\section{Copyrights}

Copyright for this article is retained by the author(s), with first publication rights granted to the journal.

This is an open-access article distributed under the terms and conditions of the Creative Commons Attribution license (http://creativecommons.org/licenses/by/4.0/). 